ISSN 0258-7122

Bangladesh J. Agril. Res. 38(4): 563-572, December 2013

\title{
EFFECT OF ZINC, BORON AND MOLYBDENUM ON THE SEED YIELD OF CARROT (Daucus carota L.)
}

\author{
H. C. MOHANTA ${ }^{1}$, M. M. HOSSAIN ${ }^{2}$, M. S. AlAM ${ }^{3}$ \\ M. H. REZA ${ }^{4}$ AND M. M. ISLAM ${ }^{5}$
}

\begin{abstract}
An experiment was conducted at the research field of Bangabandhu Sheikh Mujibur Rahman Agricultural University, Salna, Gazipur during October 2006 to May 2007 to evaluate the effects of zinc, boron, and molybdenum on the seed yield of carrot. The soil of the studied field was deficient in zinc, boron, and molybdenum and represents Salna Series of Shallow Red Brown Terrace under Madhupur Tract (AEZ-28). Four (4) levels each of zinc (0, 2.0, 4.0, and 6.0 $\mathrm{kg} / \mathrm{ha})$, boron $(0,1.0,2.0$, and $3.0 \mathrm{~kg} / \mathrm{ha})$ and molybdenum $(0,0.5,1.0$, and 1.5 $\mathrm{kg} / \mathrm{ha}$ ) were used to formulate 11 treatment combinations to observe their effects on the seed yield of carrot (cv. Bejo Shetal). A blanked dose of $\mathrm{N}_{120} \mathrm{P}_{54} \mathrm{~K}_{150} \mathrm{~S}_{20}$ $\mathrm{kg} / \mathrm{ha}$ was also applied to nourish the crop. The experiment was laid out in a randomized complete block design with three replications. The seed yield of carrot was significantly increased due to integrated effects of zinc, boron and molybdenum. The highest seed yield (362.28 kg/ha) was found with $\mathrm{Zn}_{4.0} \mathrm{~B}_{2.0} \mathrm{Mo}_{1.0} \mathrm{~kg} /$ ha combination, which was $283 \%$ higher over control. The maximum germination percentage (91.30) and vigor index (4.99) of seed was also recorded from the same treatment package and thus may be recommended for the production of carrot seed in the studied or alike area of the country.
\end{abstract}

Keywords : Carrot, seed yield, zinc, boron, molybdenum.

\section{Introduction}

Carrot (Daucus carota L.) is the most economically important vegetable crops in the world, among the top-ten vegetables in terms of both area of production and market value (Simon et al., 2008). Development of flower stalk takes place only after exposure of plants to low temperature from $4.8^{\circ} \mathrm{C}$ to $10^{\circ} \mathrm{C}$ for a period ranging from 28 to 42 days at any time during the period of root development and maturity. Seed stock emerges as soon as plants are further exposed to higher temperatures from $12.2^{0} \mathrm{C}$ to $21.1^{\circ} \mathrm{C}$ (Singh and Mishra, 2004). In carrot cultivation, macronutrients are needed for normal growth, but for seed crop, micronutrients are very much essential for seed set and development, which finally effects on the seed yield. Amongst micronutrients, boron and zinc play a

\footnotetext{
${ }^{1,5}$ Principal Scientific Officer, Tuber Crops Research Centre (TCRC), Bangladesh Agricultural Research Institute (BARI), Gazipur-1701, ${ }^{2}$ Professor, Banghabandhu Sheikh Mujibur Rahman Agricultural University (BSMRAU), Gazipur-1706, ${ }^{3}$ Senior Scientific Officer, TCRC, BARI, Gazipur-1701, ${ }^{4}$ Principal Scientific Officer, ARS, Burirhat, Rangpur, Bangladesh.
} 
major role in enhancing the growth and yield of vegetable crops. Boron plays key role in cell wall development, cell division, cell extension, and pollen growth which affect seed as well as fruit set, whereas zinc is directly or indirectly required by several enzyme systems, auxins and in protein synthesis, enhancing the seed production and rate of maturity (Sharma et al., 1999). They found that foliar spray of $0.1 \%$ boric acid and application of $10 \mathrm{~kg} \mathrm{ZnSO}$ per hectare in soil application were most effective for increasing pods per plant, diameter of main shoot, seed yield, 1000-seed weight, and germination percentage of radish cv. Japanese White. It was found that boron increased seed yield of carrot (cv. Chantenay) by $5.31-23.47 \%$, while zinc by $7.35-16.07 \%$ (Homutescu et al., 1993).

Rahman et al. (2001) carried out an investigation to the effect of integrated nutrient management and liming in Grey piedmond soil on cabbage seed production (cv. Provati) and found significantly higher number of pods/plant, seeds/pod, and seed yield due to application of Mg, Zn, B, and Mo. The highest seed yield of cabbage (254 kg/ha) was obtained due to integrated use of $15,5,2$, $1 \mathrm{~kg}$ of Mg, Zn, B, and Mo per hectare, respectively. Talukder et al. (1999) studied the effect of micro nutrients on radish seed production in acid soil and found the highest seed yield of $1.8 \mathrm{t} / \mathrm{ha}$ by applying 15 , 4, and $2 \mathrm{~kg} / \mathrm{ha}$ of $\mathrm{Mg}$, $\mathrm{Zn}$ and B, respectively. Noor et al. (1996) studied the response of cauliflower to added boron and molybdenum. They recorded the highest curd yield of cauliflower by the application of $1.5 \mathrm{~kg} \mathrm{~B}$ and $1.5 \mathrm{~kg}$ Mo per hectare. They further observed that curd yield was decreased due to higher doses of boron and molybdenum. However, necessary information regarding the optimum dose of micronutrients particularly $\mathrm{B}, \mathrm{Zn}$, and Mo for seed yield of carrot under Bangladesh condition are scanty. The optimum dose of micronutrient play a decisive role in achieving seed yield potential of carrot. However, very little attention have so far been paid towards the scientific way of seed production of carrot in Bangladesh. In these context, the present investigation has, therefore, been undertaken to observe the role of zinc, boron, and molybdenum on the production of carrot seed and to find out the optimum dose of said nutrients for maximizing the seed yield of carrot under Bangladesh agro-climatic conditions.

\section{Materials and Method}

An experiment was conducted at the research field of Bangabandhu Sheikh Mujibur Rahman Agricultural University, Salna, Gazipur during October 2006 to May 2007. The experimental site was located in the centre of the Madhupur Tract at about $24^{\circ} 23^{\prime}$ north latitude and $90^{\circ} 08^{\prime}$ east longitude having a mean elevation of $8.4 \mathrm{~m}$ on the sea level. The soil of the experimental field belongs to Salna series of Shallow Red Brown Terrace Soil. The soil is silty clay loam in texture and acidic in nature being characterized by poor fertility status and 
impeded internal drainage. The initial soil was analyzed following Agro Service International method (Hunter, 1984) and the results are presented in Table 1. Zinc and boron contents were low while molybdenum content was just above the critical level.

Table 1. Chemical properties of initial soil of the experimental field (0-30 $\mathrm{cm}$ depth).

\begin{tabular}{lcc}
\hline Soil properties & Analytical value & Critical value \\
\hline $\mathrm{P}^{\mathrm{H}}$ & 6.2 & - \\
Organic matter (\%) & 1.17 & - \\
Total N (\%) & 0.088 & 0.075 \\
Available P $(\mu \mathrm{g} / \mathrm{g})$ & 31.25 & 14.0 \\
Exchangeable K (meq/100 g) & 0.37 & 0.2 \\
Exchangeable Ca (meq/100 g) & 5.39 & 2.0 \\
Exchangeable Mg (meq/100 g) & 1.65 & 0.8 \\
Available S $(\mu \mathrm{g} / \mathrm{g})$ & 13.6 & 14.0 \\
Available Zinc $(\mu \mathrm{g} / \mathrm{g})$ & 1.86 & 2.0 \\
Available Boron $(\mu \mathrm{g} / \mathrm{g})$ & 0.13 & 0.20 \\
Available molybdenum $(\mu \mathrm{g} / \mathrm{g}$ soil) & 0.05 & 0.06 \\
\hline
\end{tabular}

The seeds of carrot (cv. Bejo Shetal) were sown on 22 October 2006. The experiment was laid out in a Randomized Complete Block Design (RCBD) with three replications in a plot size $1.5 \times 1.0 \mathrm{~m}$ having row to row and plant to plant spacing of $30 \mathrm{~cm}$ and $15 \mathrm{~cm}$, respectively. The plots were raised by $15 \mathrm{~cm}$ from the ground level. The unit plots and blocks were separated by $0.75 \mathrm{~m}$ and $1.0 \mathrm{~m}$, respectively. There were eleven treatment combinations comprising four levels of boron $(0,1.0,2.0$ and $3.0 \mathrm{~kg} / \mathrm{ha})$ from boric acid $(17 \% \mathrm{~B})$, four levels of molybdenum (0, 0.5, 1.0 and $1.5 \mathrm{~kg} / \mathrm{ha}$ ) from ammonium molybdate (54\% Mo) and four levels of zinc (0, 2.0, 4.0, and $6.0 \mathrm{~kg} / \mathrm{ha}$ ) from zinc oxide (78 \% $\mathrm{Zn})$ as chemical fertilizers, respectively. The treatment combinations are shown in Table 2.

The treatments were applied through soil application. The land was fertilized with the blanket dose of NPKS at the rate of $120,54,150,20 \mathrm{~kg} / \mathrm{ha}$, respectively, as recommended by Mitra (1990). The entire quantity of TSP and gypsum, half of urea and MP were applied during final land preparation. The rest half of urea and MP were applied in two equal installments at 40 and 70 days after planting by side dressing about $5 \mathrm{~cm}$ away along the crop row. Intercultural operations like irrigation, weeding, mulching, earthing up, etc. were done as and when needed. The seed carrot was harvested periodically from 188 to 198 days after planting. Data from ten plants selected randomly from the middle rows of individual plots were collected on different seed yield parameters and yield. 
Analysis of variance was done according to Gomez and Gomez (1984). Differences between means were evaluated by Duncan`s Multiple Range Test (DMRT) following MSTAT-C programme.

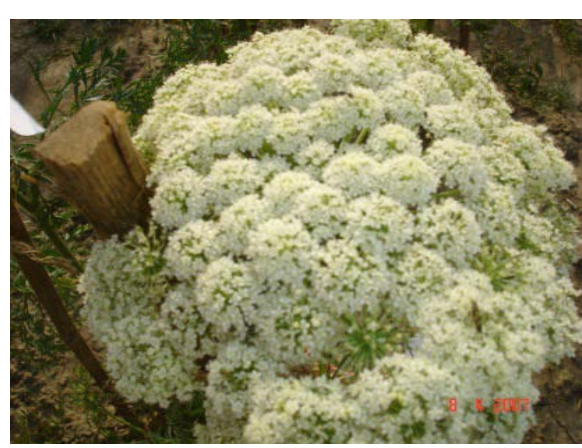

1. a. Flowering stage

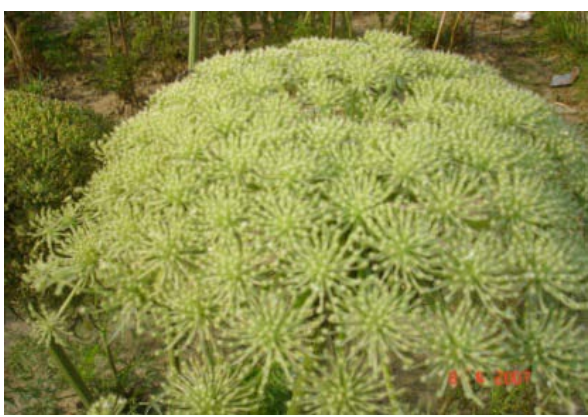

1. b. Fertilization stage

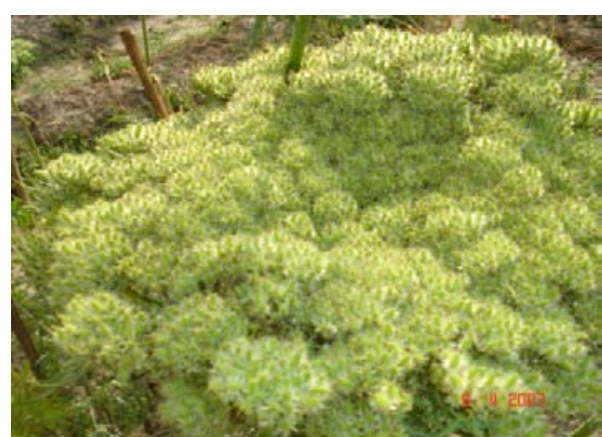

1. c. Matured stage

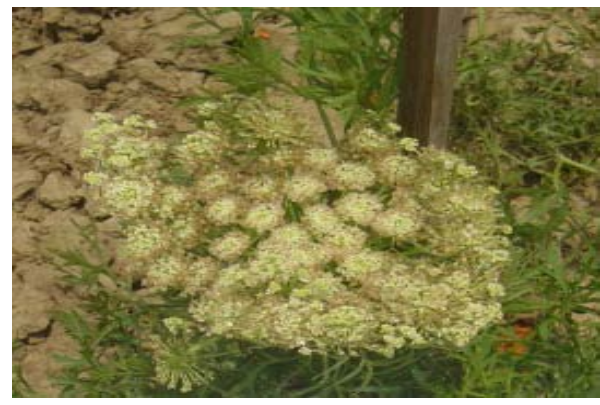

1. d. Control plot flower

Fig. 1. Flower umbel of carrot seed crop as influenced by zinc, boron, and molybdenum application $\left(\mathrm{Zn}_{4.0} \mathbf{B}_{2.0} \mathrm{Mo}_{1.0} \mathrm{~kg} / \mathrm{ha}\right)$ in comparison to control.

\section{Results and Discussion}

\section{Plant height}

Plant height, days to flower opening, number of leaves per plant, umbel diameter, and height, number of umbellate/umbel, days to seed harvest, seed yield, and quality of carrot as influenced by zinc, boron, and molybdenum are shown in Table 2, 3, and Fig. 2 and 3. All the parameters were significantly influenced by the application zinc, boron, and molybdenum. The highest plant height (94.67 $\mathrm{cm})$ was found in $\mathrm{T}_{4}\left(\mathrm{~B}_{2.0} \mathrm{Zn}_{4.0} \mathrm{Mo}_{1.0} \mathrm{~kg} / \mathrm{ha}\right)$, which was significantly higher than other treatments. The lowest plant height $(76.67 \mathrm{~cm})$ was observed in $T_{1}$ $\left(\mathrm{B}_{0} \mathrm{Zn}_{0} \mathrm{Mo}_{0} \mathrm{~kg} / \mathrm{ha}\right.$ ) (Table 2). Integrated effect of zinc, boron, and molybdenum might have resulted in increased plant height. This result agrees with the findings of Singh and Mishra (2004). 


\section{Days to flower opening}

There was a pronounced variation in days to flower opening due to application of micronutrient. The early (137 days) flowering was observed in $\mathrm{T}_{4}\left(\mathrm{Zn}_{4.0} \mathrm{~B}_{2.0} \mathrm{Mo}_{1.0}\right.$ $\mathrm{kg} / \mathrm{ha}$ ) and delayed (155 days) flowering was in the control $\left(\mathrm{T}_{1}\right)$ (Table 2). The second lowest days to flowering (142.30) was recorded in $T_{11}$, which was statistically similar to $T_{5}$, but significantly lower than rest of the treatments except $\mathrm{T}_{4}$. The days to flower opening in different treatments varied possibly due to effects of applied micronutrients. This result is in agreement with the findings of Yadav et al. (2004).

\section{Umbel diameter}

Umbel diameter was also increased significantly due to integrated use of zinc, boron and molybdenum (Table 2). The biggest umbel diameter $(18.40 \mathrm{~cm})$ was recorded in $\mathrm{T}_{4}\left(\mathrm{Zn}_{4.0} \mathrm{~B}_{2.0} \mathrm{Mo}_{1.0} \mathrm{~kg} / \mathrm{ha}\right)$, while it was smallest $(9.33 \mathrm{~cm})$ in control $\mathrm{T}_{1}\left(\mathrm{Zn}_{0} \mathrm{~B}_{0} \mathrm{Mo}_{0} \mathrm{~kg} / \mathrm{ha}\right)$. However, the umbel diameter of six different treatment combinations, namely $T_{5}, T_{6}, T_{7}, T_{8}, T_{10}$, and $T_{11}$ was statistically similar (Table 2). These results indicate that variation in different levels of zinc, boron, and molybdenum were not so pronounced in terms of umbel diameter although integrated use of these nutrients are required.

\section{Number of umbellate per umbel}

Wide variation was found in respect of number of umbellate/umbel due to addition of micronutrient. The maximum number of umbellates (68.34) per umbel was found in $\mathrm{T}_{4}\left(\mathrm{Zn}_{4.0} \mathrm{~B}_{2.0} \mathrm{Mo}_{1.0} \mathrm{~kg} / \mathrm{ha}\right)$, which was statistically similar to $\mathrm{T}_{5}\left(\mathrm{Zn}_{4.0} \mathrm{~B}_{3.0} \mathrm{Mo}_{1.0} \mathrm{~kg} / \mathrm{ha}\right), \mathrm{T}_{6}\left(\mathrm{Zn}_{0} \mathrm{~B}_{2.0} \mathrm{Mo}_{1.0} \mathrm{~kg} / \mathrm{ha}\right), \mathrm{T}_{7}\left(\mathrm{Zn}_{2.0} \mathrm{~B}_{2.0} \mathrm{Mo}_{1.0} \mathrm{~kg} / \mathrm{ha}\right), \mathrm{T}_{8}$ $\left(\mathrm{Zn}_{6.0} \mathrm{~B}_{2.0} \mathrm{Mo}_{1.0} \mathrm{~kg} / \mathrm{ha}\right), \mathrm{T}_{10}\left(\mathrm{Zn}_{4.0} \mathrm{~B}_{2.0} \mathrm{Mo}_{0.5} \mathrm{~kg} / \mathrm{ha}\right)$ and $\mathrm{T}_{11}\left(\mathrm{Zn}_{4.0} \mathrm{~B}_{2.0} \mathrm{Mo}_{1.5} \mathrm{~kg} / \mathrm{ha}\right)$ (Table 2). The minimum number of umbellate/umbel (34.90) was obtained in $\mathrm{T}_{1}$ $\left(\mathrm{Zn}_{0} \mathrm{~B}_{0} \mathrm{Mo}_{0} \mathrm{~kg} / \mathrm{ha}\right)$.

\section{Days to seed harvest}

Days to seed harvest of carrot was significantly influenced by the application of said micronutrients (Table 2). Days to harvest ranged from 166.73 to 185.13 , having the maximum days recorded in $\mathrm{T}_{1}\left(\mathrm{Zn}_{0} \mathrm{~B}_{0} \mathrm{Mo}_{0} \mathrm{~kg} / \mathrm{ha}\right)$ in control and the minimum days in $\mathrm{T}_{4}\left(\mathrm{Zn}_{4.0} \mathrm{~B}_{2.0} \mathrm{Mo}_{1.0} \mathrm{~kg} / \mathrm{ha}\right)$. However, variation in different levels of added micronutrients appeared to be non-significant although their combined applications are necessary to have easier seed set and maturity. Tandon and Roy (2004) reported that boron plays an important role in pollen tube growth which affects seed and fruit set and enhanced final yield. They also reported that $\mathrm{Zn}$ is directly or indirectly involved in several enzymes particularly dehydrogenises, auxin and protein synthatase which enhance the rate of maturity of seeds. 
Table 2. Effect of zinc, boron, and molybdenum on the plant development characters of carrot seed crop.

\begin{tabular}{l|c|c|c|c|c}
\hline \multicolumn{1}{c|}{ Treatments } & $\begin{array}{c}\text { Plant } \\
\text { height }\end{array}$ & $\begin{array}{c}\text { Days to } \\
\text { flower } \\
\text { opening }\end{array}$ & $\begin{array}{c}\text { Umbel } \\
\text { diameter } \\
\text { (cm) }\end{array}$ & $\begin{array}{c}\text { No. of } \\
\text { umbellate/ } \\
\text { umbel }\end{array}$ & $\begin{array}{c}\text { Days to } \\
\text { seed harvest }\end{array}$ \\
\hline $\mathrm{T}_{1}=\mathrm{Zn}_{0} \mathrm{~B}_{0} \mathrm{Mo}_{0}$ & $76.67 \mathrm{e}$ & $155.03 \mathrm{a}$ & $9.33 \mathrm{f}$ & $34.90 \mathrm{~d}$ & $185.13 \mathrm{a}$ \\
$\mathrm{T}_{2}=\mathrm{Zn}_{4.0} \mathrm{~B}_{0} \mathrm{Mo}_{1.0}$ & $79.00 \mathrm{e}$ & $148.02 \mathrm{~b}$ & $11.33 \mathrm{e}$ & $48.31 \mathrm{c}$ & $176.71 \mathrm{~b}$ \\
$\mathrm{~T}_{3}=\mathrm{Zn}_{4.0} \mathrm{~B}_{1.0} \mathrm{Mo}_{1.0}$ & $84.33 \mathrm{~d}$ & $146.09 \mathrm{~cd}$ & $13.90 \mathrm{~cd}$ & $59.28 \mathrm{~b}$ & $173.25 \mathrm{bc}$ \\
$\mathrm{T}_{4}=\mathrm{Zn}_{4.0} \mathrm{~B}_{2.0} \mathrm{Mo}_{1.0}$ & $94.67 \mathrm{a}$ & $137.05 \mathrm{~g}$ & $18.40 \mathrm{a}$ & $68.34 \mathrm{a}$ & $166.73 \mathrm{~d}$ \\
$\mathrm{~T}_{5}=\mathrm{Zn}_{4.0} \mathrm{~B}_{3.0} \mathrm{Mo}_{1.0}$ & $88.33 \mathrm{bc}$ & $144.01 \mathrm{ef}$ & $15.83 \mathrm{bc}$ & $61.10 \mathrm{ab}$ & $170.72 \mathrm{~cd}$ \\
$\mathrm{~T}_{6}=\mathrm{Zn}_{0} \mathrm{~B}_{2.0} \mathrm{Mo}_{1.0}$ & $89.00 \mathrm{bc}$ & $146.31 \mathrm{bcd}$ & $15.00 \mathrm{bcd}$ & $60.58 \mathrm{ab}$ & $172.70 \mathrm{bc}$ \\
$\mathrm{T}_{7}=\mathrm{Zn}_{2.0} \mathrm{~B}_{2.0} \mathrm{Mo}_{1.0}$ & $86.00 \mathrm{~cd}$ & $145.07 \mathrm{de}$ & $15.67 \mathrm{bc}$ & $60.23 \mathrm{ab}$ & $173.82 \mathrm{bc}$ \\
$\mathrm{T}_{8}=\mathrm{Zn}_{6.0} \mathrm{~B}_{2.0} \mathrm{Mo}_{1.0}$ & $88.67 \mathrm{bc}$ & $145.06 \mathrm{de}$ & $14.39 \mathrm{bcd}$ & $61.62 \mathrm{ab}$ & $171.46 \mathrm{c}$ \\
$\mathrm{T}_{9}=\mathrm{Zn}_{4.0} \mathrm{~B}_{2.0} \mathrm{Mo}_{0}$ & $84.33 \mathrm{~d}$ & $147.43 \mathrm{bc}$ & $13.53 \mathrm{~d}$ & $62.27 \mathrm{ab}$ & $174.37 \mathrm{bc}$ \\
$\mathrm{T}_{10}=\mathrm{Zn}_{4.0} \mathrm{~B}_{2.0} \mathrm{Mo}_{0.5}$ & $87.72 \mathrm{bc}$ & $144.81 \mathrm{de}$ & $14.78 \mathrm{bcd}$ & $62.50 \mathrm{ab}$ & $171.31 \mathrm{c}$ \\
$\mathrm{T}_{11}=\mathrm{Zn}_{4.0} \mathrm{~B}_{2.0} \mathrm{Mo}_{1.5}$ & $90.00 \mathrm{~b}$ & $142.30 \mathrm{f}$ & $16.00 \mathrm{~b}$ & $63.61 \mathrm{ab}$ & $172.24 \mathrm{bc}$ \\
\hline $\mathrm{CV}(\%)$ & 7.10 & 9.35 & 5.40 & 5.72 & 8.12 \\
\hline
\end{tabular}

In a column, means followed by common letters are not significantly different from each other at $5 \%$ level of probability by DMRT.

\section{Number of seeds per plant}

Distinct variation was observed for number of seeds per plant due to application of zinc, boron and molybdenum (Table 3). The maximum number of seeds (8271.51) was obtained in $\mathrm{T}_{4}\left(\mathrm{Zn}_{4.0} \mathrm{~B}_{2.0} \mathrm{Mo}_{1.0} \mathrm{~kg} / \mathrm{ha}\right)$, followed by that in $\mathrm{T}_{5}$ $\left(\mathrm{Zn}_{4.0} \mathrm{~B}_{3.0} \mathrm{Mo}_{1.0} \mathrm{~kg} / \mathrm{ha}\right)$ with 7964.61 number of seed per plant and the minimum (2777.24) in $\mathrm{T}_{1}\left(\mathrm{Zn}_{0} \mathrm{~B}_{0} \mathrm{Mo}_{0} \mathrm{~kg} / \mathrm{ha}\right)$. Sharma et al. (1999) reported that highest number of pods per plant (947.78) due to $1 \%$ foliar application of boric acid and highest number of pods per plant by the application of $10 \mathrm{~kg} / \mathrm{ha} \mathrm{ZnSO}_{4}$ in soil application on radish.

\section{0-Seed weight}

The 1000 -seed weight varied significantly from $0.89 \mathrm{~g}$ to $1.70 \mathrm{~g}$ due to application of zinc, boron, and molybdenum (Table 3). The lowest 1000-seed weight (0.89 g) was found in control $\mathrm{T}_{1}\left(\mathrm{Zn}_{0} \mathrm{~B}_{0} \mathrm{Mo}_{0} \mathrm{~kg} / \mathrm{ha}\right)$ and the highest 1000seed weight found in $\mathrm{T}_{4}\left(\mathrm{Zn}_{4.0} \mathrm{~B}_{2.0} \mathrm{Mo}_{1.0} \mathrm{~kg} / \mathrm{ha}\right)$. Jana and Mukhopadhyay (2002) reported maximum 1000-seed weight of cauliflower ( $3.4 \mathrm{~g}$ ) for the application of $20 \mathrm{~kg}$ borax along with $1.5 \mathrm{~kg}$ sodium molibdate and $25 \mathrm{~kg} \mathrm{ZnSO} 4$ per hectare. 
Table 3. Effect of zinc, boron, and molybdenum on the seed yield components and some seed quality parameters of carrot seed crop.

\begin{tabular}{l|c|c|c|c|c}
\hline Treatment & $\begin{array}{c}\text { No. of seeds/ } \\
\text { plant }\end{array}$ & $\begin{array}{c}1000- \\
\text { seed wt } \\
(\mathrm{g})\end{array}$ & $\begin{array}{c}\text { Germination } \\
(\%)\end{array}$ & $\begin{array}{c}\text { Co-efficient } \\
\text { of } \\
\text { germination } \\
(\%)\end{array}$ & $\begin{array}{c}\text { Vigour } \\
\text { index }\end{array}$ \\
\hline $\mathrm{T}_{1}=\mathrm{Zn}_{0} \mathrm{~B}_{0} \mathrm{Mo}_{0}$ & $2777.24 \mathrm{j}$ & $0.89 \mathrm{~h}$ & $46.00 \mathrm{~g}$ & $11.18 \mathrm{e}$ & $2.56 \mathrm{c}$ \\
$\mathrm{T}_{2}=\mathrm{Zn}_{4.0} \mathrm{~B}_{0} \mathrm{Mo}_{1.0}$ & $3807.36 \mathrm{i}$ & $1.21 \mathrm{~g}$ & $56.00 \mathrm{f}$ & $14.20 \mathrm{~d}$ & $2.83 \mathrm{c}$ \\
$\mathrm{T}_{3}=\mathrm{Zn}_{4.0} \mathrm{~B}_{1.0} \mathrm{Mo}_{1.0}$ & $4254.45 \mathrm{~h}$ & $1.30 \mathrm{f}$ & $66.00 \mathrm{e}$ & $16.14 \mathrm{bc}$ & $3.51 \mathrm{~b}$ \\
$\mathrm{~T}_{4}=\mathrm{Zn}_{4.0} \mathrm{~B}_{2.0} \mathrm{Mo}_{1.0}$ & $8271.51 \mathrm{a}$ & $1.70 \mathrm{a}$ & $91.33 \mathrm{a}$ & $18.81 \mathrm{a}$ & $4.99 \mathrm{a}$ \\
$\mathrm{T}_{5}=\mathrm{Zn}_{4.0} \mathrm{~B}_{3.0} \mathrm{Mo}_{1.0}$ & $7964.61 \mathrm{~b}$ & $1.62 \mathrm{~b}$ & $86.00 \mathrm{~b}$ & $16.24 \mathrm{~b}$ & $4.65 \mathrm{a}$ \\
$\mathrm{T}_{6}=\mathrm{Zn}_{0} \mathrm{~B}_{2.0} \mathrm{Mo}_{1.0}$ & $4615.71 \mathrm{~g}$ & $1.54 \mathrm{de}$ & $67.33 \mathrm{de}$ & $14.22 \mathrm{~d}$ & $3.56 \mathrm{~b}$ \\
$\mathrm{~T}_{7}=\mathrm{Zn}_{2.0} \mathrm{~B}_{2.0} \mathrm{Mo}_{1.0}$ & $6512.42 \mathrm{c}$ & $1.52 \mathrm{de}$ & $82.00 \mathrm{~b}$ & $15.80 \mathrm{bc}$ & $3.55 \mathrm{~b}$ \\
$\mathrm{~T}_{8}=\mathrm{Zn}_{6.0} \mathrm{~B}_{2.0} \mathrm{Mo}_{1.0}$ & $6025.28 \mathrm{~d}$ & $1.56 \mathrm{~cd}$ & $84.00 \mathrm{~b}$ & $16.25 \mathrm{~b}$ & $3.88 \mathrm{~b}$ \\
$\mathrm{~T}_{9}=\mathrm{Zn}_{4.0} \mathrm{~B}_{2.0} \mathrm{Mo}_{0}$ & $5012.35 \mathrm{f}$ & $1.50 \mathrm{e}$ & $71.33 \mathrm{~cd}$ & $15.27 \mathrm{c}$ & $3.22 \mathrm{bc}$ \\
$\mathrm{T}_{10}=\mathrm{Zn}_{4.0} \mathrm{~B}_{2.0} \mathrm{Mo}_{0.5}$ & $5702.50 \mathrm{e}$ & $1.53 \mathrm{de}$ & $76.00 \mathrm{c}$ & $16.15 \mathrm{bc}$ & $3.54 \mathrm{~b}$ \\
$\mathrm{~T}_{11}=\mathrm{Zn}_{4.0} \mathrm{~B}_{2.0} \mathrm{Mo}_{1.5}$ & $6087.53 \mathrm{~d}$ & $1.60 \mathrm{bc}$ & $82.00 \mathrm{~b}$ & $16.61 \mathrm{~b}$ & $3.87 \mathrm{~b}$ \\
\hline $\mathrm{CV}(\%)$ & 7.19 & 5.87 & 2.93 & 2.41 & 7.43 \\
\hline
\end{tabular}

In a column, means followed by common letters are not significantly different from each other at $5 \%$ level of probability by DMRT.

\section{Germination (\%)}

The seed germination percentage varied significantly due to added micronutrients (Table 3). In case of control, only $46.00 \%$ seeds were germinated which raised to as high as $91.33 \%$ with $\mathrm{T}_{4}\left(\mathrm{Zn}_{4.0} \mathrm{~B}_{2.0} \mathrm{Mo}_{1.0} \mathrm{~kg} / \mathrm{ha}\right)$. The second highest germination (86.00\%) was recorded in $T_{5}$, which was statistically identical to $T_{7}, T_{8}$ and $T_{11}$ but significantly higher over rest of the treatments except $\mathrm{T}_{4}\left(\mathrm{Zn}_{4.0} \mathrm{~B}_{2.0} \mathrm{Mo}_{1.0}\right.$ $\mathrm{kg} / \mathrm{ha}$ ). Yadav et al. (2004) found that the germination percentage of carrot seed was $96.33,89.33$ and $76.00 \%$ for primary, secondary and tertiary umbel, respectively.

\section{Co-efficient of germination (\%)}

Fast germination determines the better success of seedling establishment under field conditions. Significant variation was observed in co-efficient of germination due to different micronutrient combinations. The highest co-efficient of germination (18.81 \%) was found in $\mathrm{T}_{4}\left(\mathrm{Zn}_{4.0} \mathrm{~B}_{2.0} \mathrm{Mo}_{1.0} \mathrm{~kg} / \mathrm{ha}\right)$, which was significantly higher over rest of the treatments (Table 3). The lowest co-efficient of germination (11.18\%) was found in the control $\mathrm{T}_{1}\left(\mathrm{Zn}_{0} \mathrm{~B}_{0} \mathrm{Mo}_{0} \mathrm{~kg} / \mathrm{ha}\right)$. Yadav et al. (2004) also found $13.75 \%$ higher coefficient of germination in carrot. 


\section{Vigour index}

Pronounced variation was reflected as to the vigour index of carrot seeds due to different levels of micronutrient combinations. It ranged from 2.56 to 4.99 (Table 3 ). The highest vigour index was recorded in $\mathrm{T}_{4}\left(\mathrm{Zn}_{4.0} \mathrm{~B}_{2.0} \mathrm{Mo}_{1.0} \mathrm{~kg} / \mathrm{ha}\right)$, which was closely followed by $\mathrm{T}_{5}\left(\mathrm{Zn}_{4.0} \mathrm{~B}_{3.0} \mathrm{Mo}_{1.0} \mathrm{~kg} / \mathrm{ha}\right)$ and the lowest vigour was recorded in $\mathrm{T}_{1}\left(\mathrm{Zn}_{0} \mathrm{~B}_{0} \mathrm{Mo}_{0} \mathrm{~kg} / \mathrm{ha}\right)$. The third highest vigour index (3.88) was observed in $T_{8}$, which was significantly higher over $T_{1}$ (control) and $T_{2}$, inferior to $T_{4}$ and $T_{5}$, but statistically identical to rest of the treatments. The result is in agreement with the findings of Shantha et al. (1998) who reported higher vigour index of 3.86 in carrot.

Remarkable variation was observed in seed yield per plant among the micronutrient combinations. The seed yield per plant ranged from $1.89 \mathrm{~g}$ to $7.24 \mathrm{~g}$ having the highest in $\mathrm{T}_{4}\left(\mathrm{Zn}_{4.0} \mathrm{~B}_{2.0} \mathrm{Mo}_{1.0} \mathrm{~kg} / \mathrm{ha}\right)$, which was significantly higher over rest of the treatments. The second highest seed yield per plant was recorded in $\mathrm{T}_{5}\left(\mathrm{Zn}_{4.0} \mathrm{~B}_{3.0} \mathrm{Mo}_{1.0} \mathrm{~kg} / \mathrm{ha}\right)$, which was also significantly higher over rest of the treatment except $\mathrm{T}_{4}$. The lowest seed yield per plant (1.89 g) was obtained from control $\mathrm{T}_{1}$. The higher number of umbellates/umbel and higher number of seeds/umbel might have contributed to produce higher seed yield/plant in $\mathrm{T}_{4}$ $\left(\mathrm{Zn}_{4.0} \mathrm{~B}_{2.0} \mathrm{Mo}_{1.0} \mathrm{~kg} / \mathrm{ha}\right)$ (Fig.2). Higher vegetative growth might have produced maximum photosynthates which resulted in increased seed yield/plant. The results are in agreement with the findings of Jacobson and Globerson (1980).

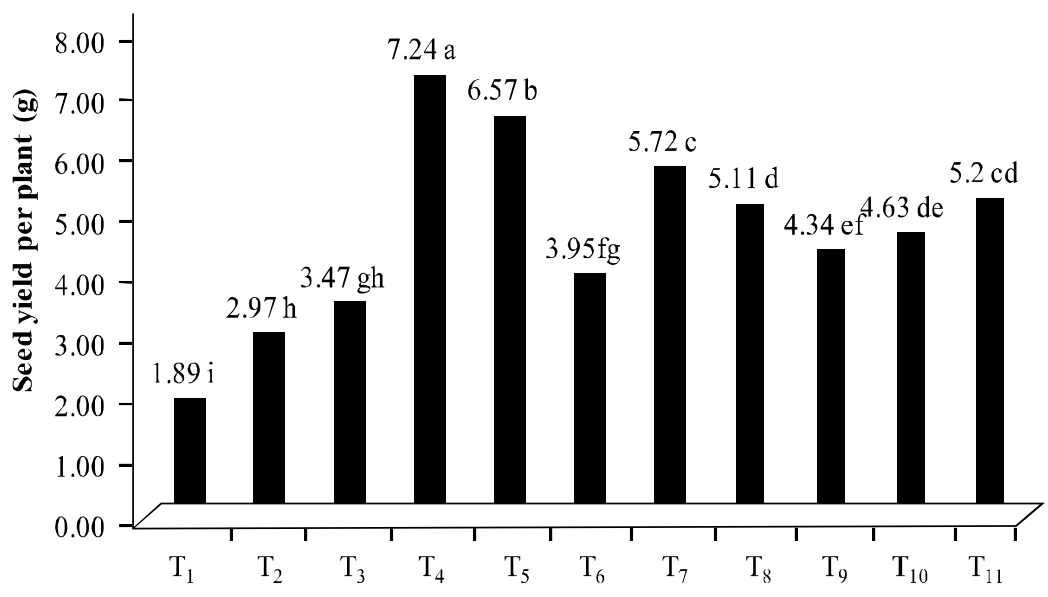

Fig. 2. Effect of zinc, boron, and molybdenum application on the seed yield per plant in carrot.

\section{Seed yield (kg/ha)}

The seed yield of carrot significantly increased due to combined application of zinc, boron, and molybdenum (Fig. 3). The highest seed yield (362.28 kg/ha) 
was obtained from $\mathrm{T}_{4}\left(\mathrm{Zn}_{4.0} \mathrm{~B}_{2.0} \mathrm{Mo}_{1.0} \mathrm{~kg} / \mathrm{ha}\right)$, which was significantly higher over rest of the treatments. The second highest seed yield (328.84 kg/ha) was recorded in $\mathrm{T}_{5}\left(\mathrm{Zn}_{4.0} \mathrm{~B}_{3.0} \mathrm{Mo}_{1.0} \mathrm{~kg} / \mathrm{ha}\right)$, which was statistically different from other treatments. In absence of zinc, boron, and molybdenum applications, only 94.67 $\mathrm{kg} / \mathrm{ha}$ seed yield was obtained, which was significantly lower than all other treatments. The highest seed yield (362.28 kg/ha) was obtained from $\mathrm{T}_{4}$ $\left(\mathrm{Zn}_{4.0} \mathrm{~B}_{2.0} \mathrm{Mo}_{1.0} \mathrm{~kg} / \mathrm{ha}\right)$, which was $283 \%$ more than untreated control. The results showed that integrated use of three vital micronutrients ( $\mathrm{Zn}, \mathrm{B}$, and Mo) produced significantly higher seed yield over their missing doses either one or any two of the applied micronutrients as well as control, which reveal their essentiality in boosting up the seed yield of carrot. Raymond (1985) reported that the seed yield of carrot in tropical region is usually lower $(250 \mathrm{~kg})$ than the European types $(300 \mathrm{~kg})$.

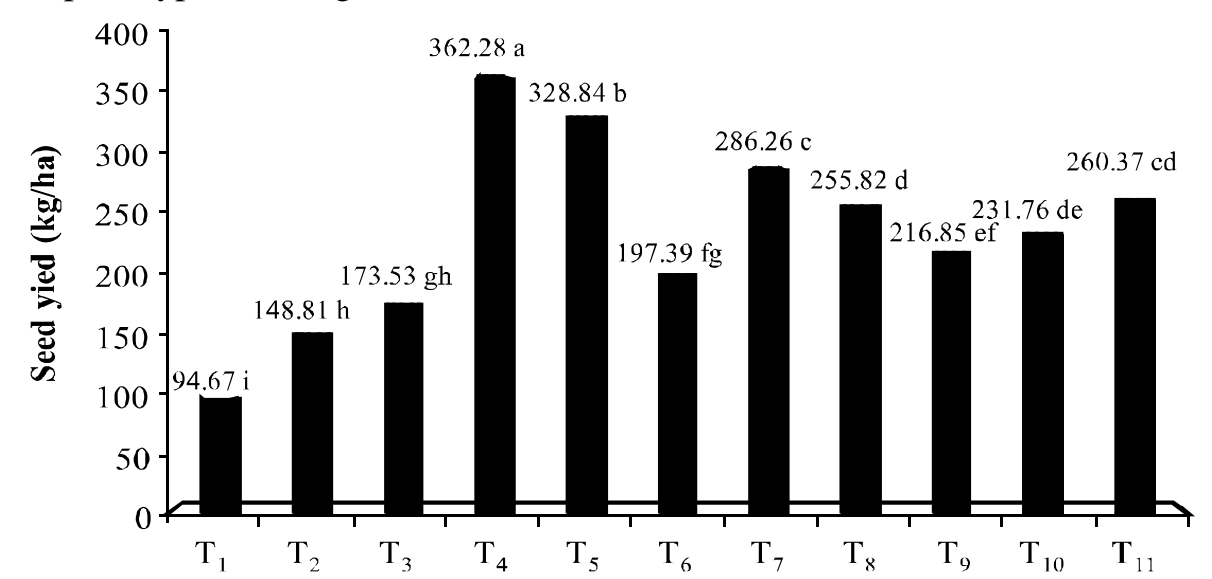

Fig. 3. Effect of zinc, boron, and molybdenum application on seed yield of carrot.

\section{Conclusion}

The carrot seed crop (cv. Bejo Sheetal) responded significantly to the combined application of zinc, boron, and molybdenum. A package of $\mathrm{Zn}_{4.0} \mathrm{~B}_{2.0} \mathrm{Mo}_{1.0} \mathrm{~kg} / \mathrm{ha}$ along with a blanket dose of $\mathrm{N}_{120} \mathrm{P}_{54} \mathrm{~K}_{150} \mathrm{~S}_{20} \mathrm{~kg} / \mathrm{ha}$ appeared to be optimum for the maximization of carrot seed yield in Shallow Red Brown Terrace Soil under Madhupur Tract. Thus the said treatment package may be recommended for the production of carrot seed in the study and alike areas of the country.

\section{References}

Gomez, K. A. and A. A. Gomez. 1984. Statistical procedures for Agricultural Research. ( $2^{\text {nd }}$ Ed.) John Willey \& Sons, New York. P. 680.

Homutescu, V., A. Cozaceanu and I. Cozaceanu. 1993. The influence of micronutrients boron and zinc on the production of carrots. Lucr. Sti. Inst. Agron. Iasi. Pp.223-230. 
Hunter, A. H. 1984. Soil fertility analytical services in Bangladesh. Consultancy report. Bangladesh Agricultural Research Project, Phase-II, BARC, Dhaka, Bangladesh.

Jacobsohn, R and D. Globerson. 1980. Daucus carota (carrot) seed quality: II. The importance of the primary umbel in carrot seed production. In : Seed production, P. D. Hebblethwaite (ed.). Pp. 637-46.

Jana, J. C. and T. P. Mukhopadhyay. 2002. Yield and quality of cauliflower seeds as influenced by added boron, molybdenum and zinc in West Bengal. Bangladesh J. Agril. Res. 27 (1): 1-4.

Mitra, S. K., M. K. Sadhu and T. K. Bose. 1990. Nutrition of vegetable crops. Naya prokash publishing, Calcutta 700006, India. P. 442.

Noor, S., M. Rahman, N. C. Shil, S. K. Nandy and M. N. Anwar. 1996. Effect of boron and molybdenum on the yield and yield components of cauliflower. Bangladesh Hort. 24 (1\&2): 123-127.

Rahman, M., M.N. Anwar, N.C. Shil, W. Sultana and K.H. Talukder. 2001. Production of cabbage seed as influenced by integrated nutrient management and liming in Grey Piedmont Soil. Bangladesh J. Sci. \& Tech. 3(1): 35-40.

Raymond, A. T. G. 1985. Vegetable seed production. $1^{\text {st }}$ edition, Longman Publishing Group Ltd. pp. 318.

Shantha, N., V. K. Pandita and S. Deepti. 1998. Effect of sowing time and umbel order on emergence characteristics of Asiatic carrot Daucus carota L. Seed Research 26(2): 125-130.

Sharma, S. K., H. Singh and U. K. Kohli. 1999. Influence of boron and zinc on seed yield and quality in Radish. Seed Research 27(2) : 154-158.

Simon, P. W, R. E. Freeman, J. V. Vieira, L. S. Boiteux, M. Briard, T. Nothnagel, B. Michalik and Y. Kwon. 2008. Carrot. In: Prohens, J., Nuez, F.(eds.) Handbook of Plant Breeding, Vol. 2. New York, NY: Springer. Pp. 327-357.

Singh, R. V and A. C. Mishra. 2004. Effect of spacing and nitrogen levels on seed yield in carrot (Daucus carota L.) cv. Nantes. Seed Research Vol. 32(1): 36-38.

Talukder, A. S. M. H. M., S. M. Nabi, H. Reza and H. Mohanta.1999. Annual Research Report, Soil and Water Section, HRC, BARI, Joydebpur, Gazipur. Pp. 8-13.

Tandon, L.S. and R.N.Roy. 2004. Integrated nutrient management-a glossary of terms. Jointly published by the Food and Agriculture Organization of the United Nations, Rome and Fertilizer Development and Consultation Organization, New Delhi.

Yadav, S. K., B. S. Dhankhar, R.S. Sangwan and R. P. S. Tomar. 2004. Effect of umbel order and seed size on seed quality in carrot (Daucus carota L.). Seed Research 32(2): 154-159. 